\title{
6 \\ Just War Thought and the Notion of Peace
}

\author{
James G. Murphy
}

The goal of this chapter is to explore the notion of peace appropriate to just war thought. Some just war principles generate a number of inferences about peace.

Traditionally, just war thinking has been divided into two areas of moral concern: jus ad bellum, concerned with the political decision to go to war, and jus in bello, addressing the conduct of war. In recent years, two new areas have emerged: jus post bellum and jus ex bello. Both are concerned with the end or aftermath of war: jus post bellum focuses on what ought to be done after victory, jus ex bello looks at the moral aspects of continuing or exiting a war under circumstances where victory is unlikely. ${ }^{1}$ Each derives from jus ad bellum, since treatment of war's goals and the conditions under which it should be terminated have in the past come under jus ad bellum.

J.G. Murphy $(\bowtie)$

Department of Philosophy, Loyola University Chicago, Chicago, IL, USA e-mail: jmurphy7@luc.edu 


\section{Jus in Bello: Peace as the Absence of War}

In discussing peace in relation to war, I deal first with jus in bello, since there is less to be said than is the case with jus ad bellum.

Jus in bello thought became prominent in the early modern period of the sixteenth and seventeenth centuries, as jus ad bellum thinking receded owing to the recognition by legal theorists that, while there might be such a thing as natural law, there was no supranational authority or, for most purposes, any enforceable international law. Without them, the notions of legitimate authority and just cause were inapplicable in any informative sense. Among early modern theorists, Vitoria notes the difficulty of determining that only one side has just cause. Gentili holds that there can be justice on both sides, so the "rights of war" must apply to both parties. Grotius follows Cicero in holding that waging war is not inconsistent with the "laws of nature." Hobbes takes that position to its logical conclusion in holding that natural law requires states to fight to promote their interests. ${ }^{2}$ Their views (though not Suarez's) amounted to abandoning jus ad bellum principles.

Jus in bello concerns the conduct of war, as well as the treatment of enemy soldiers, prisoners, and non-combatants. Back then, it also dealt with the forms to be observed when initiating war, in particular the stateto-state formal declaration of war, along with notifying their respective citizens that a state of war now existed. ${ }^{3}$ It could also include issuing a formal ultimatum prior to declaration of war. Some of these forms have evolved into the contemporary notion that UN permission should be obtained before going to war (except when under direct attack).

In the jus in bello perspective, peace is simply the absence of formal war. War is legally and morally permissible only if it observes certain norms and limits, and jus in bello norms aim at minimizing the negative effects of the state of war.

\section{Jus in Bello: War and Peace as States-of-Affairs}

Thus, in jus in bello thinking, war and peace are mutually exclusive statesof-affairs, with peace constituted by the absence of war. Grotius is probably the first to make explicit the notion of war and peace as states-of-affairs: 
Cicero defined war as a "contention by force." A usage has obtained, however, which designates by the word not an action but a state (non actio sed status); thus war is a state of those contending by force, viewed simply as such. ${ }^{4}$

This legal view of war and peace as mutually exclusive states captures the core idea of early modern jus in bello thinking by jurists and rulers. Arguably, it has continued to be a, if not the, foundational element in what we today think of as traditional just war theory up to 1914.

It indicates a rough notion of peace, characterized by the following elements. First, peace is to be understood as a legally normative state of affairs, equivalent to a state of non-war. In a given instance, the peace in question may be characterized by an arms race, border tensions, economic or technological sabotage, or (internally) civil unrest and ethnic resentment. But that would still be peace, within the meaning of jus in bello's legal notion of peace. In the jus in bello perspective, the Cold War that lasted nearly half a century was not a war.

Second, only established states have the right to engage in war, and that right is subject to their fulfilling various legal formalities in launching war and in treating the other state's soldiers and civilians. Outside of those boundaries, any military action, particularly rebellion, was deemed criminal, analogous to piracy and banditry. Social injustice and internal political oppression were normally excluded from being relevant to the morality of war.

Third, war and peace are all-or-nothing states; they are not matters of degree, e.g., being more peaceful or less peaceful. Fourth, political trends towards war or towards peace can play no role within jus in bello.

Fifth, considering war and peace as states-of-affairs abstracts from the agents, i.e., the governments, responsible for creating or choosing war, as well as from its causes and justification (if any), and the belligerents' intentions. It is concerned only with the agents' conduct of the war.

Accordingly, jus in bello implies that peace is: (a) a state of affairs, (b) defined legally, not politically or morally (where morality is independent of law), as a formal absence of war, and (c) committing states to elaborate procedures and restrictions if they decide to terminate it by going to war. 


\section{Jus ad Bellum's Paradox: War Intends Peace}

Jus ad bellum thought addresses the war decision and the use of war to achieve certain goals that include peace. It concerns moving from peace to war and from war to peace. Accordingly, it has significant implications for how peace is to be understood.

Classical or pre-modern jus ad bellum thought (e.g., Aquinas) looked to notions of legitimate authority, just cause, and right intention to provide the basic framework for evaluating the morality of war-making. Restoring a lost or threatened peace and stability was the duty of legitimate authority, just cause was constituted by threats to peace and order or to the lives of a significant number of the populace, and right intention aimed at the defeat of those who had unjustly started war or insurrection and the restoration of peaceful order.

A contemporary version of jus ad bellum thought (1) might expand who could qualify as legitimate authority to include the leaders of insurrectionary groups and a variety of non-state institutions, (2) would support in principle the claim that the seeds of war are sown by oppression and injustice, and (3) would (at least in the line of thinking found in recent jus post bellum thought) consider that the victorious powers had a moral responsibility to establish some elements of a just social order in the defeated state. Items (2) and (3) are relevant to the kind of peace just war thought is interested in. They also appear to set standards for peace. 5

As regards just cause, if peace were simply the absence of a state of war, any going to war would be an attack on peace and hence morally unjustifiable. But in taking it that war could be justified or even morally required, the jus ad bellum tradition indicates that the emergence of just cause means the formal peace that may still exist is significantly reduced in moral value. Augustine goes so far as to say it is no longer a genuine peace, since its continuance now depends upon submission to aggression or worse. ${ }^{6}$ Even if none of the other jus ad bellum conditions were met, the possibility that a just cause for going to war could sometimes exist implies that the value of peace is not absolute or always overriding. That is the first key element in the just war tradition's notion of peace. 
Right intention has traditionally been taken to mean intending or aiming at peace. But (as Augustine remarked) even the wars of aggressors ultimately intend peace. ${ }^{7}$ Right intention must therefore aim at a peace that meets certain moral standards: peace with justice, or peace with a sufficiently just international order. The notion of right intention implies that, as well as the value of peace, other values would have to be promoted, both for their own sake and because they make peace more secure. The second key element in the jus ad bellum notion of peace is that the right intention criterion indicates that the value of peace can be realized only when its implementation is integrated with at least partial realization of certain other values.

In the ideal scenario, where the aggressor has been defeated, the victors' intention would be to undo or rectify the injustice or aggression that gave just cause for the war. But it may be that as the war progresses it becomes clear that they may have to settle for less than complete rectification of the injustice, since the cost of such rectification may now be disproportionate to the good to be attained. This is the scenario where the value of peace may outweigh some of the other values. In short: while the formal peace of the absence of war may be of lesser value in jus ad bellum thought, a comprehensive peace may not be morally possible, so that the wronged party may have to settle for an imperfect peace that does not rectify all or even most of the injustices that constituted just cause for going to war in the first instance. ${ }^{8}$ The rationally assignable relative weighting given to peace and other particular values may change during the course of the war. This is a third element in the jus ad bellum notion of peace.

\section{Like War, Peace Emerges from a Context}

In jus in bello thought, peace and war are relatively static notions, defined (in part) by various legal criteria, for the purposes of identifying the duties and rights of combatants and non-combatants. Jus in bello concepts and principles do not address peace or war as such, since they apply only within the framework of an ongoing war. 
By contrast, while most attention is paid to jus ad bellum thought at times when war is imminent, it is also relevant during times of peace. At the time of writing (2016), the US government is aware that there is some probability of future conflicts with Russia, China, North Korea, or Iran. War with any of those countries is not at present imminent or likely, so there is scope for crafting and implementing policies that might avert war with those states. Not merely would that be generally desirable, it is also what jus ad bellum implies should be done. If a crisis occurred in a few years' time between the United States and one of those states, it would be hard for the United States to claim it had just cause for going to war or to persuade anybody (including itself) that it was capable of morally realistic right intention if in the previous years it had been oblivious to the risk of war and had done little to manage conflict or deter aggression, or if its earlier responses had been overly placatory or overly aggressive. Similarly, if a few years from now the United States found itself deciding on war with one of those states, what would be required to meet the right intention condition then would probably be required now as a matter of political prudence.

Historiographical works on the causes of particular wars usually have much to say about states' political failures and miscalculations in the years prior to the war. While law plays a primary role with respect to jus in bello requirements, its role is smaller-and more ambiguous-with respect to jus ad bellum. Here, the historian and political scientist play a larger role, since the causes of war are rooted in cultures, national needs, and state policies that precede the war, often by many years. While the range of what could count as just cause and as right intention is limited by legal constraints, their specification cannot be ahistorical and apolitical: what qualifies as just cause and what qualifies as right intention are to a significant degree contextual, which means that it is not just a matter of ethics and law, but also a matter of history and politics. History indicates that the just cause criterion has two implications for governments: (1) Don't give other countries just cause to go to war with you; (2) Within reason, so conduct your policies that you do not unexpectedly find yourself with a just cause for war under circumstances in which war is hard to avoid. The law cannot replace the political art of historically informed management of international relations.? 
Ontologically, in jus ad bellum thought, peace is more aptly viewed as a relation than as a state-of-affairs. The development of effective international law is unquestionably desirable, and helps reduce the scope for war. But its enforcement depends upon the good will, the power, and the interests of the sovereign states, and these change, for better or worse, through their relations with other states.

The classical just war tradition viewed the state's right as based upon its duty to protect the people. Its contemporary version refuses to conflate protection of the people with national self-defense, noting that the people ought not necessarily be thought of as just the state's own citizens. ${ }^{10}$ The possibility of morally warranted resort to war is part of a theory of good governance, which includes helping to maintain international order and protecting the oppressed, and to build whatever peace would be politically practical in the context of that twin commitment.

While international law is important in relation to those goals, it is not enough: there is no algorithm or formal decision procedure that could fully replace the role of human political judgment of when war is necessary, prudent, or justified (three different judgment types). (Even if there were such a formal decision procedure, implementing or imposing it would amount to an undemocratic disempowerment of the peoples of the various nations.) Law can go some way towards determining the conditions under which going to war would be permissible, but it offers less with respect to when going to war would be necessary, and even less with respect to when going to war might be morally required of one's own country. ${ }^{11}$

Just cause and right intention notions imply that peace, of the "thick" politically substantial kind, as distinct from the formal kind, is not a given, once a peace treaty has been signed. To use a common slogan: after one has won the war, one must then win the peace. That is a matter of developing a certain kind of relation between the two states, and maybe even their peoples as well. Building the peace relation between the state and other states or relevant non-state agents requires a number of coherent policies consistently followed over a number of years. These policies and actions should aim to promote order and protect people's rights, by a range of policy tools including: military intervention, peace enforcement, armed deterrence, arms reduction, outright war, measured concessions, being willing to suffer and tolerate certain provocations, and other options. 


\section{The Practical Goal of Imperfect Peace}

In the mid-nineteenth century, British jurist Sir Henry Maine remarked: "War appears to be as old as mankind, but peace is a modern invention." 12 This counterintuitive idea merits teasing out.

While there were short-lived peace movements in medieval Christendom, it was not until the Enlightenment that the idea of abolishing war was seriously mooted. The catastrophe of two world wars and the arrival of nuclear weapons generated a new urgency about eliminating war. Under modern conditions, it was hard to credit the view that war was anything but fundamentally irrational. Yet despite general acceptance of that claim, peace remained elusive. On occasion, governments might find they no longer knew how not to go to war. Sometimes, controlled initial moves towards preparation for war, intended to deter, might trigger a chain of events leading to an out-ofcontrol escalation into full-scale war.

On the other hand, calls for universal or unilateral disarmament were neither plausible nor persuasive when proposed in a way that cavalierly ignored nations' reasonable and durable interests. Given these complexities, the idea of inventing peace expressed the intuition that the only way to find out what peace is to see what works first, leaving theorizing until afterwards.

Mere absence of armed conflict, even when accompanied by serious injustice, might still in some contexts be enough peace to satisfy people. Where a war drags on with no end in sight, with high casualties and considerable collateral harm to the civilian population, the populace would probably be glad of a simple cessation of the violence. ${ }^{13}$ Formal peace is not completely without value.

At the other end of the scale would be the Kantian idea of perfect peace. While unrealizable, and dangerous if taken to be realizable, it could function as a kind of regulative ideal shaping the way governments and peoples work for peace. What people would view as a decent peace, imperfect enough to be practically achievable, would still involve considerably more than the mere absence of violence. That is the kind of peace to which jus ad bellum is oriented. 
(1) An imperfect decent peace depends on building a political relationship.

After the formal peace settlement, the political relations that ground peace must be built. After World War II, relations between West Germany and its former enemies in the West were uncertain and sometimes uneasy into the early 1960s. The German leaders were unsure of whether its former enemies would allow it to reindustrialize or to create its own army, later whether they would sustain it against encroachment by the USSR, and later yet whether they were merely tactical allies against the USSR or were genuine friends. At the time of German reunification in 1990, German uncertainty about its allies' attitudes received some confirmation in French and British reluctance to endorse reunification, which was counterbalanced by the United States' unequivocal support. Even half a century after World War II, the peace process was not entirely complete.

(2) An imperfect decent peace is the morally appropriate goal.

In modern times, while ethics is seen in certain quarters as nebulous or even subjective, law is viewed as more serious and objective in relation to establishing a global justice. Yet the legal approach is inevitably drawn to absolute notions of war and peace, for once the law is in place it must be obeyed, regardless of political circumstances or prudential judgment. Jus in bello principles can be given a significant degree of legal embodiment. But attempting to come up with law that determines, for any government, the circumstances under which it is prohibited, permitted, or required to go to war would be overreach that might on some occasions do more harm than good, not to mention that it would effectively eliminate governments as legitimate authorities relative to war and peace, replacing them solely with the law (or the UN). ${ }^{14}$ Such perfectionism in this area is politically naïve, and that is a moral failing. Jus post bellum thought perhaps relied on an image of war overly focused on the United States' military engagements in the 1980-2003 period with the hope that great military power should be able to guarantee comprehensive political justice thereafter. Here, war's end and subsequent peace could be thought of primarily in legal terms. But such cases represent only a tiny minority of wars and their endings.

A morally and legally perfect peace is rarely attainable. The Enlightenment dream that with enough law and just social structures 
war would (as Marx said of the state) "wither away" naturally died in the horrors of the twentieth century: we now know too much history, and know far more than did the Enlightenment about the dark side of the human subconscious and its atavistic impulses. ${ }^{15}$ To the extent that the tacit ideal of perfect peace easily attainable shapes people's interpretation of the jus ad bellum criteria, it generates an excessively stringent apolitical interpretation of them that will either point towards the waging of total war, or else make the just war tradition converge on pacifism. Each outcome undermines jus ad bellum thinking.

(3) That an imperfect decent peace may be a cause of later wars is morally tolerable, provided the peace holds for a significant period of time.

Most peace settlements contain the seeds of future wars. No matter how carefully the peace settlement is crafted, sooner or later subsequent historians will trace at least some of the causes of a later war to that settlement. But it would be unreasonable to take this fact as necessarily rendering the settlement morally flawed. Just as there could be no war to end war (other than one that wiped out the human race), so there can be no peace settlement that eliminates the need for future such settlements.

Where it is obvious to the relevant governments at the time of the settlement that the peace they propose has a high probability of leading to war in the not-so-distant future, they act wrongly in imposing such a peace. A similar verdict can be rendered in cases where the peace terms are so onerous for the defeated parties (e.g., the terms of the March 1918 Treaty of Brest-Litovsk between the Central Powers and Russia) that they will probably repudiate them at the first opportunity. In such cases, there are good grounds for arguing that the treaty fails to intend peace, and intends instead either conquest or strategic positioning for a future war with the defeated power, neither of which could be morally acceptable.

Here I am concerned with the cases where the peace treaty is not obviously flawed in such a fashion, and seems to reasonable observers to give some hope for future peace between the former belligerents. Even in such cases, it is the rare peace settlement that lasts for more than a century.

Even where the defeated power is not meditating revenge or resumption of the war at the earliest opportunity, even where the victor's government is not planning on ignoring the restraints of the treaty to take unfair advantage 
of the defeated country, it is still the case that some of the unintended consequences of the war and its conclusion may include conditions increasing the probability of a subsequent war. Compared to the 1918 Treaty of BrestLitovsk, the various treaties of 1919-1920 with the defeated Central Powers were less predatory, and to some extent aimed at doing justice to formerly subject peoples, and yet they too were bitterly resented by the defeated countries, notably Germany and Hungary. As can be expected, grossly unjust peace-treaties have a high probability of generating future war, but even relatively just and moderate peace treaties may, in historical hindsight, serve to make war more likely. ${ }^{16}$

The 1815 Congress of Vienna was relatively successful in stabilizing Europe after the upheaval of the Napoleonic wars, if the fact that there was no general European war for the next 100 years can be taken as evidence for that claim. Of course, since there were numerous smaller European wars after 1815, it would be foolhardy to claim that the Congress settlement had no causal role in relation to subsequent wars. But, since eighteenth century Europe had suffered four major continent-wide wars, and since no general European war occurred between 1815 and 1914, the Congress of Vienna's peace settlement appears comparatively successful.

That imperfect achievement, even if partly a matter of luck, must suffice from a moral viewpoint: the way a war is ended must be judged relatively successful if it is followed by at least 30 years' peace between the belligerents. Even the armed stalemate between North Korea and South Korea since 1953 would seem, certainly to Koreans who lived through the ravages of the Korean war (1950-1953), to count as a relative success in providing peace and stability for a half century.

In cases where former enemies become allies, perhaps friends, as Japan and Germany became US allies and friends after World War II, or Prussia and Austria became allies and friends after their brief war in 1866 , it counts as a very successful peace-making, even if one of the causes of its success is the fear of a mutual enemy. These outcomes or aftermaths of war suggest the value for a government (like the United States), envisaging the rising probability that it may have to go to war with a certain country, of thinking through what jus ad bellum's right intention criterion would mean, not just for the war and its termination, but also for the subsequent future relationship with that country. 
(4) An imperfect peace provides the opportunity for, and a fragile peace may even give impetus to, reforms that promote justice, thereby reducing the probability of future conflict.

This condition is particularly applicable in the case of intercommunal or ethnic conflict. People value peace not just for the good of not having armed clashes in their towns and cities, but also for the goods that are made possible by the absence of armed conflict. ${ }^{17}$ The goods of a populace that is fed and reasonably secure, of a working economy, of a functioning legal system and some protection of people's rights, depend on the existence of an organized society not torn apart by war or even constantly destabilized by low-level conflict. Such a society where those goods obtain might still fall short of being a just society, but at least it is a functioning society, of some value to ordinary people compared to prolonged anarchy. The point is: such a society is sufficiently secure that it can afford to spend less on its military and more on feeding, educating, and enriching its citizens. The fruits of peace enhance the peace.

Approaching the issue from the other side, wars and social disorder arise from the failure of good governance, and failure of the state to provide those social goods makes for war and conflict. ${ }^{18}$

The idea that peace has to be constructed can sound either utopian or grim. The utopian sound occurs when it is taken (often by pacifists) to mean that with good will, peace can be constructed and going to war will never even seem necessary. ${ }^{19}$ The grim note is struck by the political realist who holds that, while no particular war is inevitable, the world is unlikely ever to be completely free of war. The pacifist says: "If you want peace, work for justice, and you won't have to fight." The realist says: "If you want peace, work for justice, and be prepared to fight for them." Michael Howard remarks that the victors in World War II drew the realist inference: "In the process [of the war] it had become clear that military power was necessary not only to the establishment, but also to the preservation of peace." ${ }^{20}$ After 1945, small European countries like Norway, Denmark, Netherlands, and Belgium abandoned their previous neutrality in favor of collective security; so, notably, did the United States. The option for collective security is based on the hard lesson that preserving peace requires a realistic military policy and a proportionate military establishment capable of fighting a serious war. A peace-preserving military must also actively keep up to date, for just 
as certain forms of war become obsolete, so the forms of feasible peace may also change over time. ${ }^{21}$

\section{Building the Peace-Relation}

I have argued that peace is better understood as a relation than as a state of affairs. Classifying it as a relation directs attention to the entities that it relates, which, in the context of the ethics of war, are political agents (whether individual heads of government or communities). A number of points can be added.

First, the quality of the relation will vary from instance to instance. In 2017, the United States is at peace with Japan and at peace with China, so here are two peaceful relations involving the United States. The US-Japan peace-relation is considerably deeper and stronger than is the US-China peace-relation. Japan is an ally of the United States and has a similar political system, whereas China has a different political system, and is not an ally but a rival that aims to reduce US influence in East Asia. Outbreak of war between the United States and Japan has miniscule probability, war between the United States and China at some point in the next 20 years has a non-trivial probability.

Second, relations evolve and change. Assuming neither the United States nor China wants war, each government has to develop the relation between them, while seeking to protect its own interests, in a way that ensures war does not happen. The development of the relation can be expected to include both progress and setbacks. I have, earlier in this chapter, argued that jus ad bellum's just cause and right intention require taking cognizance of the ups and downs of international relations, as well as the danger of misunderstanding and miscalculation when the quality of the peace-relation between two states is poor. In the crisis when war looms, consideration of just cause cannot be confined to focusing on one particular action taken by the other side; it must be retrospective on the recent history between the two states. The right intention condition will require not merely consideration of what strategic defeat of the other state would amount to but also some projection, of a realistic kind, of the future relation between the two states. 
Third, the idea of peace as a relation has intuitive appeal in the context of ethnic, religious, or racial intercommunal tensions periodically erupting into armed conflict. In the case of such divided communities recovering from or seeking to avoid future intercommunal conflict, treaties and other legal instruments may be infrequent. But even where they are used, it is usually in relatively acute awareness of the fact that no set of legal arrangements will alone suffice to keep the peace. ${ }^{22}$

Fourth, when each side recognizes that there are goods and benefits available to it provided it cooperates with the other side, and recognizes that international relations are not a zero-sum game and that its own long-term interests may sometimes be served by judicious assistance of the other, this amounts to a recognition of there being common goodscommon because only cooperation can achieve them. ${ }^{23}$ Even the United States and the USSR, avowed enemies throughout the Cold War era, recognized that they shared an interest in avoiding a nuclear war.

For any relation between states, communities, and persons, the bottom line of "What do I get out of it?" has to be factored in. Building peace depends upon seeing one's own state benefiting from providing some space for the other to flourish. An important part of the peacerelation will be the give-and-take of negotiating with each other, bargaining, persuading and conceding, learning from the other, and slowly working out the specifics of the concrete good of a peaceful relation.

\section{Peace: What Kind of Good?}

Christine Korsgaard has drawn attention to the difference between two distinctions in goodness or value ${ }^{24}$ : the means/end distinction and the extrinsic/intrinsic distinction. ${ }^{25}$ That clarification is helpful in relation to specifying the kind of value peace represents.

As regards the means/end distinction, the just war tradition deems peace important enough to qualify as of value as an end. There seems no need to argue for that. Interestingly, it is also good as a means. In most cases, the end of peace is promoted by peaceful means and practices, including diplomacy and judicious concessions to the interests of others, even down to using non-aggressive language, as already noted. In the case of 
two countries sliding towards war, where there is past unhappy history, yet where neither wants war and is open to negotiation, the peaceful means of renewed dialogue, compromise, mediation by others and the like are the most likely to avert war. Here peace has instrumental value, for there is just enough of a peace-relation remaining between them to make it possible to move away from war without losing face or suffering political disadvantage. Under happier conditions, where two states are friends and allies, the peace-relation is also enjoyed in the very activity of deepening that peace.

Turning to the extrinsic/intrinsic distinction, peace being a relation means that it is an extrinsic and not an intrinsic good. One of Korsgaard's purposes in making the distinction was to draw attention to the fact that something being good as an end did not mean that it was intrinsically good. That is illuminating in this context. Her distinction challenges the temptation to assume that peace being good as an end is thereby intrinsically good so that it necessarily has significant value in all circumstances, no matter how unjust or life-threatening the relational context in which it is grounded. For reasons given earlier, this view is incorrect.

Where it is realized or instantiated in a relation between two states or communities, it will be part of a network of relations between them. The holistic concrete relation between two states, where the peace between them is so deep-rooted and established that they are not merely not at war, nor even merely allies, but friends, instantiates several distinct relational or extrinsic values. The deepening of the peace-relation and the realization of its value requires a heuristic approach that can perceive that the political and public policy steps creating that concrete good may become available only as time goes by and earlier steps have been taken. Peace is a relation, and the process of deepening it does not quickly reach a terminus.

\section{Notes}

1. For a summary of jus post bellum's thought, see Orend (2005). On jus ex bello, see the Symposium on the topic in Ethics 125 (April 2015), in particular Dill (2015).

2. Reichberg et al. (2006): for Vitoria see pp. 311, 318-322; for Gentili see pp. 374-375; for Grotius see pp. 393-395, 414; for Hobbes see pp. 444-447. 
3. For convenience, I shall speak of states in this chapter. However, the UN and other international bodies, as well as the non-state political leadership of ethnic groups or communities can also qualify as legitimate authorities.

4. Reichberg et al. (2006, 393).

5. Later-developed criteria (reasonable prospect of success, last resort, proportionality) add little more to the content of jus ad bellum's notion of peace.

6. Augustine (1972), Bk XIX, chapter xii, 869: "One who has learnt to prefer right to wrong and the rightly ordered to the perverted sees that the peace of the unjust, compared with the peace of the just, is not worthy even of the name of peace." See Clausewitz (1984, 370), for a related idea: "It is only aggression that calls forth defense, and war along with it. The aggressor is always peace-loving; he would prefer to take over our country unopposed."

7. Augustine (1972), Bk XIX, chapter xii, 866-867.

8. See Murphy (2014, 102-112), and Fabre (2015, 631-652).

9. See Murphy (2014), particularly chapters 4 and 5.

10. For a fine overview of the classical theory, see Neff (2005). There are interesting parallels in Rodin (2002), with respect to self-defense not being the primary purpose of justifiable resort to war.

11. While I am in sympathy with the contemporary "Responsibility to Protect" doctrine, it is what Kant called an imperfect duty; determining its moral and political implications for particular states is not easy, and seems likely to be highly qualified.

12. Howard $(2000,1)$.

13. A case in point might be the Syrian civil war, which commenced in 2011 and still continues at the time of writing (2016), and has caused about half-a-million deaths and the displacement of 7 million people, including more than 4 million refugees.

14. See Murphy (2014), chapter 3 for argument to the effect that there is often more than one legitimate or competent authority relevant to war decisions.

15. On the aggressiveness that can drive war, see Kainz (1987), chapter 5.

16. Kennan $(1951,69)$, cites the French historian Jacques Bainville's comment on the 1919 Peace of Versailles as a peace "too mild for the hardships it contained."

17. See Murphy (2014), chapter 2, on the goods of peace. 
18. Spinoza, Political Treatise, chapter 5, section 2; cited in Reichberg et al. (2006, 452). The idea goes back to Cicero and Augustine. Aquinas states that the building of peace is the work of justice and charity; see Aquinas, Summa Theologiae, II. ii, q. 29, a. 3; cited in Reichberg et al. (2006, 174). Clausewitz's thesis that war is a continuation of politics conducted by additional means is consistent with the idea; Clausewitz (1984, 80-81, 87-89, and 605).

19. It also assumes that human beings are highly rational. See Cherniak (1986).

20. Howard $(2000,73)$, emphasis in text.

21. See Pasquino $(1993,80)$, where he remarks that war is "the concept that makes it possible to understand the forms as well as the existence of peace and order."

22. The 1998 Good Friday (or Belfast) Agreement that largely terminated conflict in Northern Ireland was a beginning, more than a conclusion. Violence was ended or suspended, in order to start on a project to which each community had politically committed itself. The project set a mutually agreed agenda for how to live with difference, acknowledge the other's political right to exist, forgive the violence inflicted by the other side and move on. They were aware that the Agreement itself would solve nothing if they didn't "work" it.

23. On these themes, see Axelrod (1984) and Cronin (2003).

24. Here, I ignore possible distinctions between goods and values.

25. Korsgaard (1996).

\section{References}

Augustine, 1972. City of God. London: Penguin.

Axelrod, Robert. 1984. The Evolution of Cooperation. New York: Basic Books. Cherniak, Christopher. 1986. Minimal Rationality. Cambridge: MIT Press.

Cronin, Bruce. 2003. Institutions for the Common Good: International Protection Regimes in International Society. Cambridge: Cambridge University Press.

Dill, Janina. 2015. Ending Wars: The Jus ad Bellum Principles Suspended, Repeated, or Adjusted? Ethics 125 (April): 627-630.

Fabre, Cécile. 2015. War Exit. Ethics 125 (April): 631-652.

Howard, Michael. 2000. The Invention of Peace. New Haven: Yale University Press. 
Kainz, Howard P. (ed.). 1987. Philosophical Perspectives on Peace. Athens: Ohio University Press.

Kennan, George. 1951. American Diplomacy 1900-1950. Chicago: University of Chicago Press.

Korsgaard, Christine. 1996. Two Distinctions in Goodness. In Creating the Kingdom of Ends, ed. Christine Korsgaard, 249-274. Cambridge: Cambridge University Press.

Murphy, James. 2014. War's Ends. Washington DC: Georgetown University Press.

Neff, Stephen. 2005. War and the Law of Nations. Cambridge: Cambridge University Press.

Orend, Brian. 2005. War. In The Stanford Encyclopedia of Philosophy, ed. Edward N. Zalta. Stanford University: Stanford. http://plato.stanford. edu/entries./war/.

Pasquale, Pasquino. 1993. Political Theory of Peace and War: Foucault and the History of Modern Political Theory. Economy and Society 22 (1): 77-88.

Reichberg, Gregory, Henrik Syse, and Endre Begby (eds.). 2006. The Ethics of War. Classic and Contemporary Readings. Malden, MA: Blackwell.

Rodin, David. 2002. War and Self-Defense. Oxford: Oxford University Press. von Clausewitz, Carl. 1984. On War. Princeton: Princeton University Press.

Open Access This chapter is licensed under the terms of the Creative Commons Attribution 4.0 International License (http://creativecommons. org/licenses/by/4.0/), which permits use, sharing, adaptation, distribution and reproduction in any medium or format, as long as you give appropriate credit to the original author(s) and the source, provide a link to the Creative Commons license and indicate if changes were made.

The images or other third party material in this chapter are included in the chapter's Creative Commons license, unless indicated otherwise in a credit line to the material. If material is not included in the chapter's Creative Commons license and your intended use is not permitted by statutory regulation or exceeds the permitted use, you will need to obtain permission directly from the copyright holder.

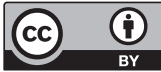

